\title{
O KONFLIKCIE INTERESÓW MIĘDZY NADZOREM A POLITYKĄ PIENIĘŻNĄ
}

Wyposażenie Europejskiego Systemu Banków Centralnych (ESBC) i Europejskiego Banku Centralnego (EBC) w uprawnienia nadzorcze nad instytucjami kredytowymi jest konsekwencją toczącej się od wielu dekad dyskusji wokół kwestii, czy między polityką pieniężną a nadzorem bankowym istnieje konflikt interesów, a w związku z tym, czy bank centralny może jednocześnie realizować obie te funkcje. Odpowiedź na to pytanie była i jest nadal przedmiotem sporów wśród przedstawicieli doktryny zajmujących się systemem bankowym (zarówno ekonomistów, jak i prawników). W różnych krajach organ sprawujący nadzór jest odmiennie usytuowany. Zresztą w różnych okresach te preferencje ulegają zmianie, nawet w tych samych państwach.

Tradycja anglosaska była przez długi czas za połączeniem polityki pieniężnej i nadzoru w banku centralnym ${ }^{1}$. Wynikało to $\mathrm{z}$ faktu, że banki centralne w tych krajach najpóźniej uzyskały niezależność od rządu. Politykę pieniężna prowadził minister finansów w imieniu rządu, a bank centralny skupiał się na działalności techniczno-operacyjnej. W koncepcji anglosaskiej bank centralny powinien znać sytuację w sektorze bankowym, gdyż jest ona przydatna do różnego typu analiz potrzebnych zarówno do realizacji polityki pieniężnej, jak i sprawowania funkcji nadzoru.

Z kolei tradycja niemiecka opowiada się za rozdzieleniem obu funkcji, ponieważ historia gospodarcza Niemiec opiera się na złych doświadczeniach okresu międzywojennego, począwszy od hiperinflacji w latach dwudziestych i kryzysu gospodarczego aż do późniejszego okresu narodowego socjalizmu i polityki wojennej III Rzeszy. Utworzenie w 1957 r. nowego banku centralnego - Bundesbanku miało na celu odbudowanie jego reputacji. Z tego też względu od początku oddzielono nadzór od Bundesbanku, tak by bank centralny nie tracił reputacji ze względu na złą sytuację w systemie bankowym i był wiarygodny w pełnieniu jednej tylko funkcji, jaka jest określanie i realizacja polityki pieniężnej. W koncepcji niemieckiej wykonywanie nadzoru ograniczałoby nieza-

\footnotetext{
${ }^{1}$ W 1997 r. nowy rząd Tony’ego Blaira przekazał nadzór z Banku Anglii do nowo utworzonego Financial Services Authority (FSA) i powstał nadzór integrujący nadzór ostrożnościowy i ochronę klientów (conduct of humans) nad wszystkimi instytucjami finansowymi (C. A. E. Goodhart, The Organisational Structure of Banking Supervision, Financial Stability Institute, Occasional Papers No. 1, November 2000-10-25, Bank for International Settlements, Basel, Switzerland).
} 
leżność Bundesbanku². Model niemiecki posłużył zreszta później jako wzór dla Europejskiego Systemu Banków Centralnych, gdyż nadzór pozostawiono w rękach państw członkowskich.

Natomiast model Banku Francji był modelem mieszanym, Komisja Bankowa była organem składającym się zarówno z przedstawicieli banku centralnego, jak i rządu․

Faktem jest, że nadzór i polityka pieniężna są pod wieloma względami odmiennymi zupełnie funkcjami. Po pierwsze - różnią się charakterem i częstotliwościa podejmowania decyzji, po drugie - zestawem informacji, które sa potrzebne do podejmowania decyzji, oraz sposobem ich realizacji, po trzecie kwalifikacjami pracowników. Do podejmowania decyzji dotyczących polityki pieniężnej wystarczą spotkania dwa razy w miesiacu, natomiast w przypadku nadzoru, zwłaszcza w okresach napięć, decyzje podejmowane są dużo częściej. Przy realizacji polityki pieniężnej dyskusja oczywiście poprzedzona jest rozesłaniem materiałów analitycznych, niemniej jednak nie wymaga tak częstych spotkań. Natomiast w przypadku nadzoru wielu sytuacji nie można ani przewidzieć, ani zaplanować. Posiedzenia organu nadzoru zwoływane mogą być ad hoc w celu podjęcia szybkich decyzji. Bardzo trudne też jest odróżnienie stanu utraty płynności banku od stanu niewypłacalności, nie każda bowiem utrata płynności musi prowadzić do niewypłacalności.

Również inne są skutki fiskalne obu funkcji. Skutki decyzji monetarnych dotyczą całej gospodarki (np. podwyżka stóp procentowych ma większe skutki finansowe dla budżetu państwa niż restrukturyzacja pojedynczego banku). $\mathrm{Z}$ punktu widzenia procedur prawnych, to większość decyzji nadzorczych jest kontrolowana przez sądy, a decyzje monetarne, jak np. podwyższenie stóp procentowych, nie podlegają takiej kontroli ${ }^{4}$.

Odmienne też są cele obu funkcji. Celem polityki pieniężnej jest stabilność cen, a celem nadzoru bankowego - stabilność systemu bankowego. Oczywiście funkcje te w pewnych obszarach się zazębiają. Na przykład restrykcyjna polityka pieniężna ma wpływ na niski poziom udzielonych kredytów, co z kolei powoduje niskie zyski banków, a więc pogarsza sytuację ekonomiczna, gdyż niższe są dochody budżetu państwa z podatków. Z kolei zbyt łagodne regulacje nadzorcze mogą mieć wpływ na konieczność podwyżki stóp procentowych, czyli na politykę pieniężna.

Konflikt może nastapić również z takiego powodu, że bank centralny pełni jednocześnie funkcję pożyczkodawcy ostatniej instancji, tzn. zaopatruje banki komercyjne w płynność, może też bank centralny, kierując się słabymi wynikami sektora bankowego, nie decydować się na podwyżkę stóp procentowych, chociaż inflacja by tego wymagała. Ponadto polityka pieniężna ma charakter procykliczny, a nadzorcze regulacje ostrożnościowe - antycykliczny, co może

${ }^{2}$ C. A. E. Goodhart zwraca uwagę, że banki centralne, nawet jeśli są formalnie i instytucjonalnie pozbawione funkcji nadzorczej, mają w praktyce duży wpływ na sprawowanie nadzoru (idem, op. cit., s. 5).

${ }^{3}$ H. Gronkiewicz-Waltz, Bank centralny - od gospodarki planowanej do rynkowej. Zagadnienia administracyjnoprawne, Warszawa 1994, s. 140.

${ }^{4}$ Instytucjonalny rozdziat agencji nadzorczych $i$ agencji kierujacych polityka pieniężna, Narodowy Bank Polski, Generalny Inspektorat Nadzoru Bankowego, Warszawa 1994, s. 4. 
powodować presję na organy nadzoru, by złagodziły swoje regulacje w okresie słabszej koniunktury. Wydaje się również, że bank centralny jest bardziej odporny na naciski polityczne niż organ nadzorczy, który na ogół jest mniej lub bardziej powiązany z rządem (np. przez system powoływania szefów nadzoru). Ale nie można wykluczyć sytuacji odwrotnej, kiedy to nadzorca chce likwidacji niewypłacalnego banku, a bank centralny, by uniknąc efektu domina, chce ten bank ratować.

Często przyczyną oddzielenia nadzoru od polityki pieniężnej jest chęć ochrony reputacji banku centralnego, która byłaby narażona na szwank, gdyby nadzorowany przez niego bank upadł, gdyż oznaczałoby to nieudolność nadzoru sprawowanego przez bank centralny ${ }^{5}$. Ponadto władze polityczne w państwach europejskich, aby zostać członkiem UE, musiały zaakceptować niezależność banku centralnego i z tego powodu były niechętne przekazywaniu mu kolejnej funkcji. Oznaczałoby to bowiem mniejszy wpływ rządu na działania organu nadzoru.

Kolejnym argumentem za niepowierzaniem nadzoru bankowi centralnemu jest fakt, że nadzór nad wszystkimi rynkami finansowymi, a nie tylko nad rynkiem bankowym, został umieszczony w jednej instytucji. Należy odpowiedzieć zatem na pytanie, czy bank centralny jest zainteresowany, by pełnić tak szeroki przedmiotowo nadzór (np. fundusze emerytalne). Z kolei jednym z istotnych argumentów za usytuowaniem nadzoru w banku centralnym jest integralność i wiarygodność systemu płatniczego. Nadzór nad systemem płatniczym w większości krajów jest realizowany przez bank centralny, który przejmuje ryzyko kredytowe i ryzyko płynności. Bank centralny może reagować szybciej niż inne organy i z tego powodu traktowany jest jako pożyczkodawca ostatniej instancji ${ }^{6}$. Dlatego stały dostęp do informacji o sytuacji banków jest dla banku korzystny, gdyż ułatwia prowadzenie zarówno polityki pieniężnej, jak i nadzorczej, zwłaszcza w okresie kryzysu.

Problemy w systemie bankowym ujawniają się najpierw w systemie płatniczym. Bank centralny, zarządzając rezerwami dewizowymi i prowadząc rozliczenia, automatycznie monitoruje w czasie rzeczywistym płynność każdego z banków ${ }^{7}$. Bank centralny nigdy nie pozbędzie się odpowiedzialności w zakresie stabilności finansowej i regulacji, zwłaszcza że kondycja systemu finansowego zależna jest od wyników makroekonomicznych ${ }^{8}$. Ponadto, aby właściwie wypełniać swoje nowe funkcje, bank centralny musi mieć dostęp do informacji na poziomie mikro ${ }^{9}$. Niektórzy autorzy uważaja, że bank centralny musi być gotowy do działania na wypadek kryzysu i oprócz wymaganych regularnych informacji ma przy okazji wiedzę, jak konkretne banki są zarządzane i przez kogo ${ }^{10}$.

${ }^{5}$ C. A. E. Goodhart, op. cit., s. 21.

${ }^{6} \mathrm{Ch}$. Goodhart, D. Schoemacher, Instytucjonalny rozdziat agencji nadzorczych $i$ agencji realizujacych politykę pieniężna, NBP, GINB, Warszawa 1994, s. 23.

7 R. Pauli, Payments remain fundamental for banks and central banks, „Bank of Finland Discussion Papers" 2000, nr 6, s. 19.

8 Ch. Goodhart, op. cit., s. 2.

9 Ibidem, s. 33.

${ }_{10}$ R. Ferguson, Alternative approaches to financial supervision and regulation, „Journal of Financial Services Research” 17(1), 2000, s. 300. 
Zdaniem Alana Greenspana nic nie jest w stanie zastapić związków między nadzorem, regulacja, zachowaniem rynków, standardów ostrożnościowych i makrostabilnościa, co z kolei jest ważne dla polityki pieniężnej. Dlatego też stabilność kompetencji (a nie ciagłe zmiany) jest bardzo ważna ${ }^{11}$.

$\mathrm{W}$ zasadzie nie istnieją przeważające argumenty na rzecz jednego z omawianych modeli. Z tego względu, kiedy określano funkcje, które ma sprawować EBC, państwa będące członkami Unii proponowały model zgodny z ich własna tradycja. Komitet złożony z prezesów banków centralnych (poprzednik Europejskiego Instytutu Walutowego - EIW) głosował przed uchwaleniem Traktatu z Maastricht za usytuowaniem nadzoru w ESBC. Propozycję tę poparła również Komisja Europejska. Komitet Prezesów uzasadnił to koniecznością posiadania informacji o sytuacji ekonomicznej banków, zwłaszcza że w długim okresie cel zasadniczy ESBC w postaci stabilności cen jest komplementarny z celem, jakim jest stabilność systemu finansowego. Pomimo poparcia Komisji dla tej koncepcji część państw członkowskich była temu przeciwna. Powody były różne, m.in. niechęć do przekazania uprawnień nadzorczych i tak już bardzo niezależnemu ESBC oraz pozbycia się kolejnych kompetencji na rzecz podmiotu ponadnarodowego. Zarówno Francja, jak i Niemcy były przeciwne przeniesieniu nadzoru na szczebel europejski. Niemcy obawiały się konfliktu interesów między polityką pieniężna a nadzorem. W kolejnych wersjach projektu statutu ESBC i EBC zmniejszano i uogólniano uprawnienia nadzorcze ESBC ${ }^{12}$.

Niemniej jednak w ówczesnym art. 105 ust. 6 Traktatu z Maastricht (obecnie art. 127 ust. 5 TfUE) znalazła się podstawa prawna do powierzenia nadzoru bankowego $\mathrm{EBC}^{13}$. Sformułowano ją w następujący sposób: ESBC przyczynia się do należytego wykonywania polityk prowadzonych przez właściwe władze w odniesieniu do nadzoru ostrożnościowego nad instytucjami kredytowymi i do stabilności systemu finansowego. Z kolei art. 28 ust. 1 Statutu ESBC uprawnia EBC do wyrażania opinii i udzielania konsultacji Radzie, Komisji i właściwym organom państw członkowskich w sprawie zakresu i stosowania ustawodawstwa Unii odnoszącego się do nadzoru ostrożnościowego nad instytucjami kredytowymi i do stabilności systemu finansowego. Niektórzy autorzy uważali, że te sformułowania są zbyt ogólne i można jedynie z nich wywnioskować, że EBC jest podmiotem, który opiniuje, ocenia i interpretuje akty unijne dotyczące nadzoru ostrożnościowego. Jest swoistego rodzaju recenzentem i cenzorem wykładni praktykowanych i stosowanych przepisów unijnych ${ }^{14}$.

Inni autorzy uważali, że rozwiązanie to jest tymczasowe, że w dłuższej perspektywie EBC będzie pełnił funkcje nadzorcze ${ }^{15}$. Zwłaszcza jeśli EBC będzie

${ }_{11}$ A. Greenspan, Testimony before the Committee on Banking, Housing \& Urban Affairs, U.S. Senate, March 2, 2005, s. 301.

${ }^{12}$ M.in. podczas przewodnictwa Holandii w 1990 r., wyłączono możliwość prowadzenia nadzoru przez EBC nad zakładami ubezpieczeniowymi. Zob. R. Smits, The European Central Bank: institutional aspects, „International Banking and Financial Law” 1997, s. 356.

${ }^{13} \mathrm{Z}$ nieoficjalnych rozmów wynika, że stało się to w wyniku nacisków Wielkiej Brytanii.

${ }^{14}$ Ch. Hadji Emmanuil, The European Central Bank and Banking Supervision, Essays in International Financial \& Economic Law, no. 3, September 1996, s. 27.

${ }_{15}$ A. Nowak-Far, Unia gospodarcza i walutowa w Europie, Warszawa 2001, s. 235. 
efektywnie prowadził politykę pieniężna, to w związku z harmonizacją regulacji nadzoru bankowego nastapi centralizacja tego nadzoru. Spowodowane to miało być ujednoliceniem warunków prowadzenia działalności przez instytucje kredytowe. Niektórzy przedstawiciele doktryny uzależniali nawet wiarygodność EBC od tego, czy będzie sprawował nadzór nad instytucjami kredytowymi $^{16}$. Widzimy więc, że rozbieżność opinii była znaczna.

Traktat nie tylko daje materialna podstawę prawną do sprawowania tego nadzoru, ale również przewiduje odpowiednią procedurę, upoważniając Radę (po konsultacji z Parlamentem Europejskim oraz EBC) do wydania rozporzadzenia, w którym może powierzyć EBC szczególne zadania dotyczące praktyk w dziedzinie nadzoru ostrożnościowego nad instytucjami kredytowymi i finansowymi z wyjątkiem instytucji ubezpieczeniowych.

W celu realizacji tych kompetencji EBC dysponuje też odpowiednimi narzędziami prawnymi: na podstawie art. 132 ust. 1 tiret 1 TfUE może wydać rozporządzenie w zakresie nadzoru ostrożnościowego. Może też podejmować decyzje niezbędne do wykonania zadań powierzonych EBC na podstawie Traktatu i Statutu ESBC i EBC (art. 132 ust. 1 tiret 2). Zanim wydano rozporządzenie w 2013 r., które wprost powierza EBC wykonywanie nadzoru ostrożnościowego, to również dotychczasowe przepisy Traktatu i Statutu ESBC i EBC uprawniały go zarówno do wydawania aktów generalnych, jak i indywidualnych.

Dodatkowym aspektem zmiany podejściu do sprawowania nadzoru przez banki centralne był fakt, że zmodyfikowano jego cele. Jeszcze przed ostatnim kryzysem coraz częściej twierdzono, że bank centralny powinien też wspierać nie tylko stabilność cen, ale również stabilność finansowa, a celem nadzoru jest właśnie stabilność finansowa. EBC w swoich opiniach do zmian ustaw o banku centralnym wskazywał na konieczność powierzenia bankowi centralnemu nowego zadania dbałości o stabilność finansową ${ }^{17}$. Obecnie, kiedy wzrasta znaczenie regulacji makroostrożnościowych, konflikt między polityka pieniężną a nadzorem staje się łagodniejszy ${ }^{18}$. Z tego względu, że stabilność finansowa, która jest celem nadzoru makroostrożnościowego, realizuje się lepiej w warunkach stabilności cen.

Umiejętna polityka pieniężna poprzez zmiany stóp procentowych może być wykorzystywana w celu łagodzenia napięć w systemie finansowym. Pogarszająca się sytuacja w sektorze bankowym może być sygnałem, że w realnej gospodarce zaczyna się dziać źle. Banki centralne reagują wówczas obniżaniem stóp procentowych. Jednakże długi okres stabilności cen nie uchronił systemu bankowego przed kryzysem. Wprost przeciwnie, stabilność cen doprowadziła do powstania bańki spekulacyjnej na rynku aktywów i wywołała kryzys. Nie oznacza to jednak, że polityka pieniężna nie wpływa już na stabilność

\footnotetext{
16 Ibidem, s. 236.

17 Opinia EBC z 2 sierpnia 2006 r. wydana na wniosek Marszałka Sejmu Rzeczypospolitej Polskiej w sprawie projektu ustawy zmieniającej ustawę o Narodowym Banku Polskim (CON/2006/39), pkt 4, s. 4.

${ }_{18}$ T. Beck, D. Gros, Monetary Policy and Banking Supervision: Coordination instead of Separation, Economic Policy, CEPS Policy Briefs, December 2012, s. 36.
} 
finansową. Wymaga jedynie dodatkowych narzędzi oprócz stopy procentowej, zwłaszcza lepszej komunikacji z rynkami. Z tego też względu ważne jest dodanie bankowi centralnemu zadania w postaci dbałości o stabilność finansowa. Oczywiście nie zmienia to faktu, że podstawowym celem banku centralnego jest stabilność cen, niemniej jednak banki centralne starają się wspierać stabilność finansowa, która wpływa pozytywnie na zrównoważony wzrost gospodarczy. Optymalne byłoby realizowanie i spełnianie obu celów, ale tak się nie zawsze dzieje.

Dzięki wcześniej przyjętym przepisom traktatowym i statutowym można było powierzyć EBC konkretne kompetencje nadzorcze ${ }^{19}$. Katalizatorem tej decyzji był oczywiście kryzys, który pokazał, że rozdrobnienie sektora finansowego może stanowić ryzyko dla wspólnej waluty i rynku wewnętrznego. Z tego względu należało pogłębić integrację obowiązków nadzorczych (motyw 2 rozporządzenia $\mathrm{nr}$ 1024/2013). To, co do tej pory było argumentem przeciwko powierzeniu EBC nadzoru bankowego, okazało się - jak wynika z motywu 13 rozporządzenia nr 1024/2013 - atutem na rzecz połączenia polityki pieniężnej i nadzoru. Ponieważ EBC jest bankiem centralnym strefy euro i dysponuje wszechstronna wiedzą specjalistyczna w zakresie makroekonomii i stabilności finansowej, jest on właściwą instytucją do wykonywania wyraźnie określonych zadań nadzorczych, ze szczególnym uwzględnieniem ochrony stabilności systemu finansowego Unii. Należy zatem powierzyć EBC szczególne zadania w odniesieniu do polityki związanej z nadzorem nad instytucjami kredytowymi w uczestniczacych państwach członkowskich. Zasady, na których opierałby się nadzór sprawowany przez EBC, określono w opinii EBC do projektu omawianego rozporządzenia. Po pierwsze, EBC powinien mieć możliwość wykonywanie zadań w sposób skuteczny i rygorystyczny bez narażania swojej reputacji. Po drugie, powinien być jak dotychczas niezależny. Po trzecie, powinien być ścisły podział między zadaniami nadzorczymi a zadaniami dotyczącymi polityki pieniężnej. Po czwarte, powinien mieć możliwość korzystania w pewnym zakresie z doświadczenia i zasobów operacyjnych krajowych organów nadzoru. Po piąte, powinien oceniać aktualną sytuację zgodnie z zasadami jednolitego rynku usług finansowych oraz zbiorem przepisów dotyczących usług finansowych $^{20}$.

Jeśli chodzi o przedmiotowy zakres europejskiego nadzoru bankowego, to zorganizowano go podobnie, jak w przypadku roli EBC w wypełnianiu funkcji polityki pieniężnej. Z tego względu, że zadania przypisane EBC są wykony-

${ }^{19}$ Na podstawie art. 18 rozporządzenia nr 1024/2013 z 15 października 2013 r., powierzajacego Europejskiemu Bankowi Centralnemu szczególne zadania w odniesieniu do polityki związanej z nadzorem ostrożnościowym nad instytucjami kredytowymi (Dz. Urz. UE L 287/63), może nakładać finansowe sankcje administracyjne w wysokości maksymalnej dwukrotności osiagniętych zysków lub unikniętych strat lub w wysokości maksymalnie $10 \%$ całkowitego rocznego obrotu.

${ }^{20}$ Opinia EBC z 27 listopada 2012 r. w sprawie wniosku dotyczacego rozporządzenia Rady powierzającego Europejskiemu Bankowi Centralnemu szczególne zadania w odniesieniu do polityki związanej z nadzorem ostrożnościowym nad instytucjami kredytowymi oraz wniosku dotyczącego rozporządzenia Parlamentu Europejskiego i Rady zmieniającego rozporządzenie (UE) nr 1093/2010 w sprawie ustanowienia Europejskiego Urzędu Nadzoru (Europejskiego Urzędu Nadzoru Bankowego), pkt 1.4, s. 7. 
wane z udziałem i za pośrednictwem krajowych organów nadzoru (ponadnarodowa polityki pieniężna EBC operacyjnie realizowana jest przez krajowe banki centralne), EBC został wyposażony w typowe kompetencje nadzorcze, m.in. wydawanie i cofanie licencji instytucjom kredytowym oraz ograniczanie zakresu ich działalności, nadzór nad nabywaniem lub zbywaniem pakietów akcji instytucji kredytowych, nadzór w zakresie przestrzegania norm adekwatności kapitału oraz dźwigni finansowej i płynności, przeznaczenia zysku na fundusze, wzywania osób prawnych lub fizycznych do udzielania wszelkich informacji, przeprowadzania inspekcji na miejscu, nakładania administracyjnych sankcji finansowych ${ }^{21}$. Natomiast EBC nie będzie się jednak zajmował zagadnieniami dotyczącymi ochrony praw konsumentów, przeciwdziałaniem praniu pieniędzy i nadzorem usług płatniczych.

Jeśli chodzi o zakres podmiotowy nadzoru EBC, to spod kompetencji krajowych organów nadzoru zostały wyjęte następujące instytucje kredytowe:

- posiadające aktywa powyżej 30 mld euro lub te, które posiadają aktywa przewyższające 20\% PKB kraju macierzystego i wyższe niż 5 mld euro lub zostana uznane za istotne przez EBC na wniosek krajowego organu nadzoru (wg kryteriów wielkości, ważności dla gospodarki kraju lub UE, wielkości działalności transgranicznej);

- trzy najbardziej znaczące instytucje kredytowe w kraju należącym do strefy euro;

- instytucje kredytowe, które otrzymały pomoc ze środków instytucji powołanych w celu stabilności finansowej lub wystapiły o jej przyznanie (Europejski Instrument Stabilności Finansowej lub Europejski Mechanizm Stabilności ${ }^{22}$.

$\mathrm{Na}$ mocy art. 6 rozporządzenia nr 1024/2013 zobowiązano zarówno EBC, jak i właściwe organy krajowe do współpracy w dobrej wierze i wymiany informacji oraz udzielania pomocy EBC w zakresie przygotowania i wdrażania wszelkich aktów, stosując się do jego instrukcji.

Aby oddzielić funkcje polityki pieniężnej od nadzoru mikroostrożnościowego i zapewnić autonomiczność procesów decyzyjnych, należało stworzyć odpowiednie struktury zarządzające. Tu pojawia się pytanie, jak zorganizować strukturę podmiotu, który sprawuje zarówno funkcję nadzorcza, jak i prowadzi politykę pieniężna, w taki sposób, aby uniknąć konfliktu interesów.

Zadania wykonywane przez EBC w ramach sprawowania nadzoru nie mogą kolidować z zadaniami związanymi z polityką pieniężną ani nie moga być od nich uzależnione, nie mogą też wpływać na bieżące monitorowanie płynności instytucji kredytowych. EBC jest zobowiązany do informowania PE i Rady o tym, jak stosuje się do tego przepisu. Personel zajmujący się wykonywaniem nadzoru jest organizacyjnie oddzielony od personelu zajmujacego się wykonywaniem innych zadań i podlega innej hierarchii służbowej. EBC ma też zapewnić, by Rada Prezesów oddzielała działalność w wykonywaniu polityki pieniężnej od wykonywania nadzoru.

W przypadku EBC pojawia się dodatkowy problem w postaci umocowania traktatowego do działania z ramienia EBC wyłącznie Rady Prezesów, a nie

21 Art. 4 rozporządzenia nr 1024/2013.

22 Art. 6 rozporządzenia nr 1024/2013. 
organu nadzorczego, którym na mocy rozporządzenia nr 1024/2013 jest Rada ds. Nadzoru. Z jednej strony art. 26 ust. 1 stanowi, że planowaniem i wykonywaniem zadań powierzonych EBC zajmuje się Rada ds. Nadzoru, z drugiej strony to Rada Prezesów przyjmuje projekty przygotowane przez Radę ds. Nadzoru. Z tego powodu Rada Prezesów ma prawo do wyrażania sprzeciwu, a ma na to nie więcej niż 10 dni roboczych. Jeśli taki sprzeciw zgłosi, Rada Prezesów przedstawia stosowne uzasadnienie na piśmie, w szczególności zawierające uwagi dotyczące polityki pieniężnej. W Regulaminie $\mathrm{EBC}^{23}$ dodano, że w zakresie nadzoru mikroostrożnościowego Rada Prezesów może nie tylko zatwierdzać, sprzeciwiać się, ale również zmieniać wnioski Rady ds. Nadzoru oraz zażądać od niej przedstawienia wniosków ${ }^{24}$. Zdaniem prezesa Bundesbanku konflikt ten można rozwiązać przez zmianę traktatu ${ }^{25}$.

Ponadto aby zapewnić oddzielenie zadań dotyczacych polityki pieniężnej od zadań nadzorczych, właściwe organy państwa, którego dotyczy sprzeciw Rady Prezesów wobec projektu decyzji Rady ds. Nadzoru, a które to organy się z nim nie zgadzaja, moga poprosić Radę ds. Nadzoru o przeprowadzenie mediacji. W skład zespołu mediacyjnego wchodzi po jednym członku spośród członków Rady Prezesów i Rady ds. Nadzoru z każdego państwa należącego do strefy euro, a wiceprezes Rady ds. Nadzoru pełni funkcję przewodniczącego. Dla każdego wniosku o przeprowadzenie mediacji zespół mediacyjny tworzy komitet do analizy przypadku, tak aby była równowaga pomiędzy członkami Rady Prezesów i Rady ds. Nadzoru. Komitet przygotowuje opinie, która z kolei przedkłada Radzie Prezesów i Radzie ds. Nadzoru. Po jej rozważeniu Rada ds. Nadzoru może przedstawić Radzie Prezesów nowy projekt decyzji.

Rozdzieleniu ulegają też posiedzenia Rady Prezesów. Te, które dotycza zadań nadzorczych, odbywaja się oddzielnie i mają odrębny porządek obrad (art. 13 Regulaminu). Oprócz podziału kompetencji i sposobu rozwiązywania sporów, ważny dla funkcjonowania struktury jest skład obu organów. Rada Prezesów składa się z Zarządu EBC i przedstawicieli banków centralnych należących do strefy euro. W skład Rady ds. Nadzoru wchodzą przedstawiciele krajowych organów nadzorczych (po jednym), czterej przedstawiciele EBC niewykonujący bezpośrednio obowiązków związanych z polityką pieniężną EBC (mianowani przez Radę Prezesów) oraz przewodniczący wyłaniany w drodze otwartej procedury kwalifikacyjnej i wiceprzewodniczący wyłaniany spośród członków Zarządu EBC. W strukturze Rady ds. Nadzoru przewagę mają przedstawiciele banków centralnych i EBC (5 EBC + 11 nadzorców), czyli nadzór de facto jest wykonywany przez przedstawicieli banków centralnych i EBC, gdyż większość europejskich nadzorów jest powiązana z bankiem centralnym.

Odpowiedź na pytanie, czy ta przewaga jest dobra, będzie zależała od tego, czy jest się zwolennikiem sprawowania nadzoru przez bank centralny czy

${ }^{23}$ Decyzja EBC z 22 stycznia 2014 r. zmieniająca decyzję EBC/2004/2 przyjmującą Regulamin Europejskiego Banku Centralnego (EBC/2014/1), (2014/179/UE), Dz. Urz. UE L 2014/95/56 (dalej jako: Regulamin).

${ }^{24}$ Art. 13h Regulaminu.

${ }^{25}$ Challenges Lie Ahead for the Single Supervisory Mechanism, Deutsche Bundesbank Eurosystem, Frankfurt am Main, 10.02.2016, s. 1. 
przez organ wydzielony. Można też zastanowić się, czy nie powinni znaleźć się w Radzie ds. Nadzoru eksperci niezależni, np. byli pracownicy nadzoru czy banku komercyjnego bądź pracownicy nauki.

Proponowany jest również dwuszczeblowy system nadzoru, który składałby się z nadzoru (5-9 członków) oraz rady składającej się z przedstawicieli krajowych nadzorców, jak również państw nienależących do Eurosystemu ${ }^{26}$.

$$
* * *
$$

W momencie utworzenia Europejskiej Unii Walutowej i Gospodarczej przeniesiono na szczebel ponadnarodowy jedynie politykę pieniężną. W mojej ocenie była to decyzja o charakterze politycznym, a nie merytorycznym. Wynikała ona z prostego faktu, że państwa członkowskie nie chciały przekazać więcej kompetencji na szczebel europejski, chcąc nadzór zachować dla siebie. Pomimo takiego podejścia zarówno w Traktacie, jak i w Statucie ESBC i EBC znalazła się podstawa prawna do wyposażenia EBC w kompetencje nadzorcze. Pomimo istnienia tej podstawy prawnej utworzono dwa organy nadzorcze na poziomie europejskim: Europejską Radę Ryzyka Systemowego w celu sprawowania nadzoru makroostrożnościowego oraz Europejski Urząd Nadzoru Bankowego w celu sprawowania nadzoru mikroostrożnościowego. Wówczas nic nie wskazywało na to, że państwa członkowskie ${ }^{27}$ skorzystaja z tej podstawy. Wydaje się, że zmiana koncepcji nastapiła na skutek obaw, że kryzys finansowy nie zostanie rozwiązany bez pełniejszego udziału EBC. W końcu zdecydowano się w 2013 r. upoważnić EBC do wykonywania nadzoru mikroostrożnościowego.

Połączenie polityki pieniężnej z nadzorem mikroostrożnościowym w EBC funkcjonuje dopiero rok. Jest to za krótki okres, aby ocenić jego efektywność. Jak wynika z informacji Reutersa, pojawiły się już pierwsze napięcia między Radą ds. Nadzoru a Radą Prezesów ${ }^{28}$. Są one skutkiem odmiennego podejścia do sytuacji w europejskim sektorze bankowym. Organ nadzoru przywiąuje wagę do wielkości kapitałów, z kolei Rada Prezesów oczekuje zdynamizowania akcji kredytowej w celu pokonania deflacji oraz przerwania powiązań między bankami a rządami, powstałymi w czasie kryzysu zadłużeniowego w strefie euro w latach 2010-2012. Przedmiotem tarć między Radą ds. Nadzoru a Rada Prezesów stały się nie tylko podwyższone przez nadzór wymogi kapitałowe, ale również wyznaczanie limitów dla posiadanych w portfelu obligacji skarbowych. Wiceprezes EBC Vítor Constâncio uważa, że taki limit może zaszkodzić bankom, rynkom finansowym i gospodarce. Pomimo tych napięć między obiema Radami żaden projekt regulacji Rady ds. Nadzoru nie został odrzucony przez Radę Prezesów, a jedynie zmieniony. Rada Prezesów znajduje się często pod presją banków, które uważaja, że nadzór europejski jest zbyt restryk-

\footnotetext{
${ }^{26}$ N. Véron, Europe's single supervisory mechanism and the long journey towards banking union, „Bruegel Policy Contribution” 2012, nr 16 (October), s. 6.

${ }^{27}$ The High-Level Group in Financial Supervision in the EU - Report, Jaques de Larsiere, Brussels, 25 February 2009.

${ }_{28} \mathrm{Zob}$. http://www.firstpost.com/fwire/exclusive-ecb-divided-over-supervisors-tough-stance-onbanks-sources-reuters-2503322.html [dostęp: 25.11.2015].
} 
cyjny. Z raportu rocznego EBC dotyczącego działalności nadzorczej za rok 2015 wynika, że zasada rozdziału zadań związanych z polityką pieniężną od zadań nadzorczych była stosowana głównie w odniesieniu do przepływu informacji między różnymi pionami EBC i opiera się na zasadzie wiedzy koniecznej (need-to-know). Zasada ta oznacza w praktyce, że poszczególne piony musiały każdorazowo udowadniać, że takie informacje są im potrzebne do realizacji zadania ${ }^{29}$.

W miarę upływu czasu łatwiej będzie ocenić, czy połączenie polityki pieniężnej i nadzoru pod jednym dachem w EBC było posunięciem korzystnym.

prof. dr hab. Hanna Gronkiewicz-Waltz

Uniwersytet Warszawski

hwaltz@wpia.uw.edu.pl

\author{
ON THE CONFLICT OF INTEREST \\ BETWEEN SUPERVISION AND MONETARY POLICY
}

\title{
Sum mary
}

The discussion involving the conflict of interest between the implementation of monetary policy and banking supervision influences the institutional solution to the question of the inclusion or non-inclusion of the supervisory function among the tasks of the central bank. Consequently, credit institutions were, for many years, left unsupervised. This situation would have probably continued until today, had it not been for the financial crisis of 2008-2013. Despite the appointment of the European Financial Supervision Office in 2011, supervision of the main EU financial institutions has recently been vested in the European Central Bank. Whether this decision was the right move will only be known in (the) years to come, when the effectiveness of this supervision has been assessed.

\footnotetext{
${ }^{29}$ Raport roczny EBC z działalności nadzorczej, marzec 2016, s. 19.
} 